\title{
EFFECT OF DIFFERENT BRANDS OF ACTIVATED CARBON ON GROWTH AND DEVELOPMENT OF COCONUT (Cocos Nucifera L) EMBRYOS IN VITRO
}

\author{
By \\ Zosimo S. Bonaobra III, Erlinda P. Rillo and Osmundo D. Orense ${ }^{1}$
}

\begin{abstract}
The effect of different brands of activated charcoal [Merck GR (Art. 2186), Sigma acid washed (C-4386), Sigma neutralized (C-3790), and Duchefa neutralized (C-1302)] on growth and development ofcoconut zygotic embryos in vitro was evaluated. Analysis of data noted after one month revealed that there was no significant difference on percentage germination, shoot length, and number of primary root of cv. Laguna Tall embryos cultured in Y3 liquid medium supplemented with $2.5 \mathrm{gll} \mathrm{AC}$ of different brands. Length of primary root of embryos cultured in Duchefa neutralized AC was significantly different from those in Sigma neutralized AC only after one month from initial culture. For the succeeding periods (2-4 months), no significant difiference was observed among the treatments in terms of increment in plant height, number of scale and true leaves and length ofprimary root. Statistical analysis revealed thatpercentage ofseedlings with primary, secondary and tertiary roots did not differ significantly among the treatments 1-4 months from initial culture. Results suggest that any brand (even alternately) can be used satisfactorily in the in vitro culture of coconut embryos.
\end{abstract}

\section{INTRODUCTION}

Activated carbon (AC) is prepared by the controlled carbonization of wood in steam or air (George, 1993). At present different brands of AC are being manufactured which according to Pierik (1987) could be obtained either from an animal or vegetable sources. However, not all brands of AC are the same and their properties differ according to the method they are prepared (George, 1993). A specific brand of AC maybe identified beneficial and/or promotory to growth and development of coconut embryos in vitro, hence this study.

\section{REVIEW LITERATURE}

Owing to its strong adsorptive properties, activated carbon (AC) is being used in many tissue culture laboratories. Like sugars, its addition to the culture medium had been considered indispensable as it is associated with better growth response of cultured tissues (Anagnostakis, 1974; Fridborg \& Eriksson, 1975; Horner et al,; 1977; Johansson \& Eriksson, 1977; Weatherhead et al., 1978; Peck \& Cumming, 1986; Bon et al; 1988; Venketeswaran et al.; 1988, Zaghmout \& Torello, 1988). It has the properties of adsorbing growth inhibitors (Fridborg et al., 1978; Weatherhead et al., 1978; 1979; Compton \& Preece, 1986; Pierik 1987; Nairn, 1988) as well as growth regulators, organic nutrients and inorganic ions (Fridborg \& Eriksson, 1975; Weatherhead et al., 1979; Nissen \& Sutter, 198 8; 1990; Ebert and Taylor, 1990; 1993).

The presence of the $\mathrm{AC}$ in the medium. sometimes leads to further adjusting the growth regulators used to a much higher concentration. Paranjothy \& Rohani (1982) had to use auxin 10 times higher in concentration to initiate embryogenic callus of oil palm. Nwanko \& Krikorian (1983) had to increase the concentration of NAA or 2,4-D from $5-10 \mathrm{mg} / \mathrm{l}$ to $10-70 \mathrm{mg} / \mathrm{l}$ in culture medium

\footnotetext{
${ }^{1}$ Tissue Culture Division, Philippine Coconut Authority-Albay Research Center Banao, Guinobatan, Albay.
} 
with $0.5 \mathrm{~g} / 1$ AC. To Krikorian (1983) had to increase the concentration of NAA or 2,4-D from 5-10 $\mathrm{mg} / \mathrm{l}$ to $10-70 \mathrm{mg} / \mathrm{l}$ in culture medium with $0.5 \mathrm{~g} / \mathrm{l} \mathrm{AC}$. To induce embryogenesis in cultures of palms, Tisserat $(1979 ; 1984)$ added $0.15-0.50 \mathrm{mM}$ 2,4-D which is accordingly 5-20 times of what is normally required. If high concentrations of AC are used, Nissen \& Sutter (1990) reported that 10-100 times more auxin should be added to a medium.

The levels of AC used in tissue culture media vary from $0.2 \%$ to $3.0 \%$ (Pierik, 1987). Tyagi et al (1980) reported that effective concentrations of charcoal for promoting embryogenesis from Datura pollen, varied according to the type of agar used. Addition of $3 \mathrm{~g} / \mathrm{l} \mathrm{AC}$ was promotory for root and shoot growth of date palm embryos (Rebechault et al., 1976; Reynolds \& Murashige, 1979). In embryo culture of coconuts, the use of $2.5 \mathrm{~g} / \mathrm{AC}$ has proven beneficial in either Y3 or MS media (Rillo \& Paloma, 1990).

This paper reports the effect of four brands of AC on the growth and development of coconut embryos in vitro.

\section{METHODOLOGY}

Ten to eleven month-old cv. Laguna Tall embryos were extracted, sterilized and initially cultured onto Y3 liquid medium following the protocol described by Rillo and Paloma (1 992). At $2.5 \mathrm{~g} / \mathrm{l}$ each, the following brands of activated charcoal were used as the treatments:

$\begin{array}{lll}\text { TI } & - & \text { Merck, GR (Art. 2186) } \\ \text { T2 } & - & \text { Sigma, acid-washed (C-4386) } \\ \text { T3 } & - & \text { Sigma, neutralized (C-3790) } \\ \text { T4 } & - & \text { Duchefa, neutralized (C-1302) }\end{array}$

For the initial culture, $40 \mathrm{~g} / \mathrm{l}$ of table grade sugar was used. The Data on the length of plumule (shoot length) length of the radicle (root length) and germination rate were noted four weeks after initial culture. Embryos were considered germinated when their shoots were about $1 \mathrm{~mm}$ long (de Guzman \& del Rosario, 1964).

Germinated embryos were transferred onto fresh Y3 liquid medium with 45 g/l sugar. Transfer interval was monthly. Plant height, leaf and root formation were noted before each subculture.

Treatments were replicated three times in a Completely Randomized Design. Data were analyzed using Analysis of Variance (ANOVA) and treatment means were compared using Duncan's Multiple Range Test.

\section{RESULTS}

Analysis of data noted after one month revealed that there was no significant difference on percentage gemiination, shoot length and number of primary root among embryos cultured in different AC treatments (Table 1). In terms of average primary root length, significant difference was observed between the neutralized brands of AC. Primary root length of embryos cultured in Duchefa neutralized AC was significantly different from those in Sigma neutralized AC. This trend, however, was not observed during the succeeding periods (2-4 months -Table 2). Both AC were comparable from the other treatments (Merck and Sigma acid washed). 
Also there was no significant difference arnong the treatments in terms of average increment in plant height and primary root length 2-4 months after initial culture (Table 2). Average primary root formation in embryos cultured in Duchefa neutralized AC was significantly different from Sigma acid washed AC. This trend, too, was not observed on the following 3-4 months. Both were com parable to Merck and Sigma

\section{neutralized brands of $\mathrm{AC}$.}

Analysis showed that there was no significant difference in terms of formation and average increment in scale and true leaves among the embryos 2-4 months after initial culture (Table 3).

Almost the same percentages in terms of seedling with primary root/s was noted among the treatments 4 months after initial culture (Table 4). Secondary and tertiary roots of embryo-cultured seedlings started to form during the second month of the culture period and onwards. When analyzed statistically, percentage of seedlings with primary, secondary and tertiary roots did not differ significantly among the treatments.

Table 1. Mean percentage germination, shoot and primary root lengths, primary root formation of germinated cv. Laguna Tall embryos cultured in Y3 Uquid medium supplemented with different brands of AC one month after linitial culture.

\begin{tabular}{|l|c|c|c|c|}
\hline \multicolumn{1}{|c|}{ AC Brand } & $\begin{array}{c}\text { Germination } \\
(\%)\end{array}$ & $\begin{array}{c}\text { Shoot Length } \\
(\mathrm{mm})^{*}\end{array}$ & $\begin{array}{c}\text { Root Length } \\
(\mathrm{mm})^{*}\end{array}$ & $\begin{array}{c}\text { Primary root } \\
\text { formation* }\end{array}$ \\
\hline Merck (M) & $65.57^{\mathrm{a}}$ & $7.42^{\mathrm{a}}$ & $13.59^{\mathrm{ab}}$ & $0.98^{\mathrm{a}}$ \\
Sigma, acid washed (SAW) & $58.57^{\mathrm{a}}$ & $6.99^{\mathrm{a}}$ & $13.34^{\mathrm{ab}}$ & $0.99^{\mathrm{a}}$ \\
Sigma neutralized (SN) & $56.84^{\mathrm{a}}$ & $7.23^{\mathrm{a}}$ & $11.68^{\mathrm{b}}$ & $0.99^{\mathrm{a}}$ \\
Duchefa, neutmlized (DN) & $62.56^{\mathrm{a}}$ & $7.43^{\mathrm{a}}$ & $14.54^{\mathrm{a}}$ & $0.99^{\mathrm{a}}$ \\
\hline
\end{tabular}

Means with the same letter are not significantly different at $5 \%$ level

*-------represents the initial data

Table 2. Average increment in plant height, root length and primary root formation 2-4 months From initial culture

\begin{tabular}{|l|c|c|c|c|c|c|c|c|c|}
\hline \multirow{2}{*}{ AC } & \multicolumn{3}{|c|}{ Plant Height $(\mathrm{mm})$} & \multicolumn{3}{c|}{ Root Length $(\mathrm{mm})$} & \multicolumn{3}{c|}{ Primary Root Formation } \\
\cline { 2 - 10 } & $2 \mathrm{mo}$ & $3 \mathrm{mo}$ & $4 \mathrm{mo}$ & $2 \mathrm{mo}$ & $3 \mathrm{mo}$ & $4 \mathrm{mo}$ & $2 \mathrm{mo}$ & $3 \mathrm{mo}$ & $4 \mathrm{mo}$ \\
\hline $\mathrm{M}$ & $17.11^{\mathrm{a}}$ & $36.99^{\mathrm{a}}$ & $57.05^{\mathrm{a}}$ & $13.47^{\mathrm{a}}$ & $7.32^{\mathrm{a}}$ & $1.04^{\mathrm{a}}$ & $0.05^{\mathrm{ab}}$ & $0.18^{\mathrm{a}}$ & $0.17^{\mathrm{a}}$ \\
$\mathrm{SAW}$ & $14.56^{\mathrm{a}}$ & $37.37^{\mathrm{a}}$ & $68.38^{\mathrm{a}}$ & $9.16^{\mathrm{a}}$ & $8.36^{\mathrm{a}}$ & $5.04^{\mathrm{a}}$ & $0.02^{\mathrm{b}}$ & $0.22^{\mathrm{a}}$ & $0.14^{\mathrm{a}}$ \\
$\mathrm{SN}$ & $15.89^{\mathrm{a}}$ & $37.01^{\mathrm{a}}$ & $71.21^{\mathrm{a}}$ & $10.48^{\mathrm{a}}$ & $12.56^{\mathrm{a}}$ & $8.54^{\mathrm{a}}$ & $0.05^{\mathrm{ab}}$ & $0.28^{\mathrm{a}}$ & $0.19^{\mathrm{a}}$ \\
$\mathrm{DN}$ & $16.62^{\mathrm{a}}$ & $42.36^{\mathrm{a}}$ & $49.50^{\mathrm{a}}$ & $9.38^{\mathrm{a}}$ & $8.39^{\mathrm{a}}$ & $0.78^{\mathrm{a}}$ & $0.10^{\mathrm{a}}$ & $0.26^{\mathrm{a}}$ & $0.12^{\mathrm{a}}$ \\
\hline
\end{tabular}

Means with the same letter are not significantly different at 5\% level 
Table 3. Initial formation and average increment of scale and true leaves 2 and 3-4 monts After initial culture, respectively

\begin{tabular}{|l|c|c|c|c|c|c|}
\hline \multirow{2}{*}{ AC } & \multicolumn{3}{|c|}{ Scale Leaf Formation } & \multicolumn{3}{c|}{ True Leaf Formation } \\
\cline { 2 - 7 } & $2 \mathrm{mo}^{*}$ & $3 \mathrm{mo} * *$ & $4 \mathrm{mo}^{* *}$ & $2 \mathrm{mo}^{*}$ & $3 \mathrm{mo}^{* *}$ & $4 \mathrm{mo}^{* *}$ \\
\hline $\mathrm{M}$ & $2.02^{*}$ & $0.80^{*}$ & $0.29^{*}$ & $0.05^{*}$ & $0.48^{*}$ & $0.36^{*}$ \\
$\mathrm{SAW}$ & $1.87^{*}$ & $0.89^{*}$ & $0.48^{*}$ & $0.04^{*}$ & $0.45^{*}$ & $0.47^{*}$ \\
$\mathrm{SN}$ & $1.88^{*}$ & $1.08^{*}$ & $0.54^{*}$ & $0.05^{*}$ & $0.46^{*}$ & $0.52^{*}$ \\
$\mathrm{DN}$ & $2.04^{*}$ & $0.80^{*}$ & $0.16^{*}$ & $0.07^{*}$ & $0.45^{*}$ & $0.46^{*}$ \\
\hline
\end{tabular}

Means with the same letter are not significantly different at $5 \%$ level

*------- initial data

**------ average increment

Table 4. Percentage of plantlets with primary, secondary and tertiary root formation 1-4 months After initial culture

\begin{tabular}{|l|c|c|c|c|c|c|c|c|c|c|c|c|}
\hline & \multicolumn{4}{|c|}{ With Primary Root/s } & \multicolumn{3}{c|}{ With Secondary Roots } & \multicolumn{3}{c|}{ With Tertiary Roots } \\
\hline & $1 \mathrm{mo}$ & $2 \mathrm{mo}$ & $3 \mathrm{mo}$ & $4 \mathrm{mo}$ & $1 \mathrm{mo}$ & $2 \mathrm{mo}$ & $3 \mathrm{mo}$ & $4 \mathrm{mo}$ & $1 \mathrm{mo}$ & $2 \mathrm{mo}$ & $3 \mathrm{mo}$ & $4 \mathrm{mo}$ \\
\hline M & $97.93^{\mathrm{a}}$ & $99.35^{\mathrm{a}}$ & $100^{\mathrm{a}}$ & $100^{\mathrm{a}}$ & $0.00^{\mathrm{a}}$ & $48.18^{\mathrm{a}}$ & $53.25^{\mathrm{a}}$ & $61.12^{\mathrm{a}}$ & $0.00^{\mathrm{a}}$ & $1.93^{\mathrm{a}}$ & $16.20^{\mathrm{a}}$ & $31.23^{\mathrm{a}}$ \\
\hline SAW & $98.70^{\mathrm{a}}$ & $99.19^{\mathrm{a}}$ & $99.19^{\mathrm{a}}$ & $99.19^{\mathrm{a}}$ & $0.00^{\mathrm{a}}$ & $36.48^{\mathrm{a}}$ & $50.67^{\mathrm{a}}$ & $61.71^{\mathrm{a}}$ & $0.00^{\mathrm{a}}$ & $4.35^{\mathrm{a}}$ & $12.33^{\mathrm{a}}$ & $30.96^{\mathrm{a}}$ \\
\hline SN & $98.83^{\mathrm{a}}$ & $100^{\mathrm{a}}$ & $100^{\mathrm{a}}$ & $100^{\mathrm{a}}$ & $0.00^{\mathrm{a}}$ & $35.63^{\mathrm{a}}$ & $52.24^{\mathrm{a}}$ & $65.83^{\mathrm{a}}$ & $0.00^{\mathrm{a}}$ & $1.62^{\mathrm{a}}$ & $21.43^{\mathrm{a}}$ & $36.28^{\mathrm{a}}$ \\
\hline DN & $98.66^{\mathrm{a}}$ & $100^{\mathrm{a}}$ & $100^{\mathrm{a}}$ & $100^{\mathrm{a}}$ & $0.00^{\mathrm{a}}$ & $36.39^{\mathrm{a}}$ & $54.97^{\mathrm{a}}$ & $57.74^{\mathrm{a}}$ & $0.00^{\mathrm{a}}$ & $1.75^{\mathrm{a}}$ & $17.75^{\mathrm{a}}$ & $19.64^{\mathrm{a}}$ \\
\hline
\end{tabular}

Means with the same letter are not significantly different at $5 \%$ level

\section{CONCLUSION AND RECOMMENDATION}

The above results suggest that any of the four brands of activated charcoal, even alternately, can be used satisfactorily in the in vitro culture of coconut embryos.

To lower the production cost, AC of the least price can be used.

\section{ACKNOWLEDGMENT}

This study was supported by the Philippine Coconut Authority (PCA), Deutcshe GesselIschaft fur Technische Zusammenarbeit (GTZ) $\mathrm{GmbH}$ and Commission of European Communities (EQ with contract no. ERBTS3*CT940298. 


\section{LITERATURE CITED}

ANAGNOSTAKIS, S.L. (1974). Haploid plants from anthers of tobacco-enhancement with charcoal. Planta 115:281-283.

BON, M.C., GENDRAUD, M \& FRANCLET, A (1988). Roles of phenolic compounds on micropropagation ofjuvenile and. mature clones of Sequoiadendron giganteum: Influence of activated charcoal. Sc. Hort.34:283-291.

COUTTON, M.E. \& PREECE, J.E. (1986). Exudation and explant establishment. Newl. I.A.P.T.C. $50: 9-18$

DE GUMVIAN, E.V. \& DEL ROSARIO, A.G. (1964).The growth and development of Cocos Nucifera L. Makapuno embryo in vitro. Phil. Agric. 48 (2-3)82-94

EBERT, A. \& TAYLOR, H.F. (1990) Assessment of the changes of 2,4-dichlorophenoxyacetic acid concentrations in plant tissue culture media in the presence of activated charcoal. Plant Cell Tiss. Org. Cult. 20:165-172

EBERT, A. \& TAYLOR, H.F. \& BLAKE, J. (1993). Changes of 6-benzylaminopurine and 2,4 dichlorophenoxyacetic acid concentrations in plant tissue culture media in the presence of activated charcoal. Plant Cell Tiss. Org. Cult. 33:157-162

FRIDBORG, G.,. \& ERIKSSON, T. (1975). Effects of activated charcoal on growth and morphogenesis. Physiol. Plant. 34:306308

FRIDBORG, G., PEDERS, M., LANDSTROM, L.E. \& ERIKSOON, T (1978). The effect of activated charcoal on tissue cultures: adsorption of metabolites inhibiting morphogenesis. Physiol. Plant. 43:104-10

GEORGE, E.F. (1 993) Plant propagation by tissue culture (2nd 3 d.) Part 1 - The Technology. Exegetics Ltd., Edington, Wilts. England. Pp. 470-471.

HORNER, M., McCONIB, J.A.McCONIB, A.J. \& STREET, H.E. (1 977).Ethylene production and plantlet formation by Nicotiana anthers cultured in the presence and absence of charcoal. $J$. Exp. Bot. 28:1365- 1372.

JOHANSSON, L. \& ERIKSSON, T. (1977). Induced embryo formation in anther cultures of several, anemone species. Physiol. Plant. 44:172-174.

NAIRN, B.J. (1988). Significance of gelling agents in a production tissue culture laboratory. Comb. Proc. Int. Plant Prop. Soc. 1987. 37:200-205

NISSEN, S.J. \& SUTTER, E.G. (1988). Stability of IAA and EBA in nutrient medium. after autoclaving and after storage under various environmental conditions. Hort Science 23:758.

NISSEN, S.J. \& SUTTER, E.G. (1990). Stability of IAA and 113A in nutrient medium to several. tissue culture procedures. Hort Science 25:800-802.

NWANKO, B.A. \& KRIKORIAN, A.D. (1983). Morphogenetic potential of embryo and seedling-derived callus of Elaeis guineensis Jacq. Var. pisifera Becc. Ann. Bot. 51:65-76 
PARANJOTHY, K. \& ROHANI, O. (1982) In vitro propagation of oil palm. In: Fujiwara, A. (Ed).pp. 747-749.

PECK, D.E. \& CUMMING, B.G. (1986). Beneficial. effects of activated charcoal on bulblet production in tissue cultures of Muscari armeniacum. Plant Cell Tiss. Org. Cult. 6:9-14

PIERIK, R.L.M. (1987) In vitro culture of higher plants. Martinus Nijhoff Publishers, Dordrecht, Netherlands. 344 pp.

REBECHAUlT, H. \& MARTIN, J.P. (1976) Callus cultures. In: Paranjothy, K (ed) A Review of tissue culture of oil palm and other palms. PORIN Occasional. Paper, No. 3 July 1982.

REYNOLD, J.F. \& MURASFHGE, T. (1979). Asexual embryogenesis in callus cultures of palms. In Vitro 15:383-387.

RILLO, E.P. \& PALOMA, M.B. (1990). Comparison of three media formulations for in vitro culture of coco embryos. Oleagianeux 45 (7):319-323

RILLO, E.P. \& PALOMA, M.B. (1992).In vitro culture of Makapuno coconut embryos. Coconuts Today 9(1):90-1 01

TISSERAT, B. (1979). Propagation of date palm (Phoenix dactylifera L.) in vitro. J. Exp. Bot. 30:1275-1283.

TISSERAT, B. (1984). Chapter 18 -------- Date palm. In Sharp et al (eds) Propagation of date palm (Phoenix dactylVera L.) in vitro. J. Exp. Bot. 30: 1275-1283.

TYAGI, A.K., RASHD, A. \& MAHESWARI, S.C. (1980). Enhancement of pollen embryo formation in Datura innoxia by charcoal. Physiol. Plant. 49:294-298

VENKETESWARAN, S. DIAS, M.A.D.L., SULTANBAWA, F. \& WEYERS, U.V. (1988). Tissue culture studies on mahogany tree. Sweitenia. In: Ahuja NM (ed.) Somatic cell genetics of woody plants. Kluwer Acadernic Publishers, Dordrecht, The Netherlands. pp. 147- 153.

WEATHERHEAD, M.A., BURDON, J. \& HENSHAW, G.G. (1978). Some effects of activated charcoal as an additive to plant tissue culture media. Z. Pflansenphysiol. 94:399-406

WEATHERHEAD, M.A., BURDON, J. \& BENSHAW, G.G.(1979). Effects of activated charcoal as, an additive to plant tissue culture media. Z. Pflansenphysiol. 94:399-406

ZAGHMOUT, O.M.F. \& TORELLO, W.A. (1988). Enhanced regeneration in Iong-term callus cultures of red fescue by pretreatment with activated charcoal. Hort Science 23:615-616. 